\title{
Tantangan Bahasa Arab sebagai Alat Komunikasi di Era Revolusi Industri 4.0 pada Pascasarjana IAIN Tulungagung
}

\author{
Ahmad Nurcholis \\ cholisahmad87@gmail.com \\ Institut Agama Islam Negeri (IAIN) Tulungagung \\ Muhamad Asngad Rudisunhaji \\ asngadiainta75@gmail.com \\ Institut Agama Islam Negeri (IAIN) Tulungagung \\ Syaikhu Ihsan Hidayatullah \\ ihsansyaikhu@gmail.com \\ Institut Agama Islam Negeri (IAIN) Tulungagung
}

\begin{abstract}
This article will describe and analyze the challenges of Arabic as a communication tool in the Industrial Revolution 4.0 era. How does the PTKIN world respond to the revolutionary changes in industry 4.0, lovers, activists, educators, and users of Arabic need to take a quick, precise, and well-prepared attitude. Therefore, the authors unearthed data at the Tulungaung IAIN Postgraduate as a Da'wah and Civilization campus that made Arabic as the main pillar in realizing that vision. The author uses a phenomenological qualitative approach. The disruption of the industrial revolution 4.0 aims to change the lifestyle of people from the real world to the virtual world in all aspects of human life such as the world of business, education, economy, governance and socio-culture in a spectacular way, but also to change people's lives and education world at large, including language education Arab. These changes, on the one hand provide opportunities or opportunities for profit, but on the other hand also provide challenges. For those who are unable to deal with it, they will incur huge losses. The findings of the study are the Tulungagung IAIN Postgraduate students who are not accustomed to applying Arabic so they have not been able to bring up the language environment. However, it has often been used in official events. It can be concluded that the Arabic language department at IAIN Tulungagung Postgraduate was able to follow the era of the industrial revolution 4.0 with articles published in both national and international journals.
\end{abstract}

Keywords: Industrial Revolution 4.0, communication, Arabic challenges 


\begin{abstract}
Abstrak
Artikel ini akan memaparkan dan menganalisis tentang tantangan bahasa arab sebagai alat komunikasi di era Revolusi Industri 4.0. Bagaimanakah dunia PTKIN merespon perubahan revolusioner industri 4.0 ini, para pecinta, pegiat, pendidik, dan pengguna bahasa Arab perlu mengambil sikap secara cepat,tepat, dan persiapan matang. Oleh karena itu, penulis menggali data di Pascasarjana IAIN Tulungaung sebagai kampus Dakwah dan Peradaban yang menjadikan bahasa Arab sebagai pilar utama dalam mewujudkan visi tersebut. Penulis menggunakan pendekatan kualitatif fenomenologis. Disrupsi revolusi industri 4.0 bertujuan mengubah gaya hidup manusia dari dunia nyata menuju dunia maya di segala aspek kehidupan manusia seperti dunia bisnis, pendidikan, ekonomi, tata negara dan sosial budaya secara spektakuler, tetapi juga mengubah kehidupan masyarakat dan dunia pendidikan secara luas, termasuk pendidikan bahasa Arab. Perubahan tersebut, di satu sisi memberi peluang atau kesempatan untuk mendapat keuntungan, tetapi di sisi lain juga memberi tantangan. Bagi pihak yang tidak mampu menghadapinya, maka ia akan mengalami kerugian besar. Hasil temuan penelitian adalah para mahasiswa Pascasarjana IAIN Tulungagung belum terbiasa menerapkan bahasa Arab sehingga belum dapat memunculkan lingkungan bahasa. Akan tetapi, sudah sering dipakai dalam acara-acara resmi. Dapat ditarik kesimpulan bahwa jurusan bahasa Arab di Pascasarjana IAIN Tulungagung mampu mengikuti era revolusi industri 4.0 dengan adanya artikel yang terbit pada jurnal baik nasional maupun internasional.
\end{abstract}

Kata kunci: Revolusi Industri 4.0, komunikasi, tantangan bahasa Arab

\title{
Pendahuluan
}

Bahasa adalah media penyalur kehendak manusia, yang memunculkan ekspresi dan menjadikan suatu kerja sama dalam masyarakat. Alat komunikasi yang dipakai oleh manusia adalah bahasa. Inilah fungsi dasar bahasa yang terlepas dari status dan nilai - nilai sosial. Setelah dihubungkan dalam kehidupan normal manusia yang di dalamnya selalu terikat dengan nilai - nilai dan status bahasa.

Kebutuhan seseorang dapat direalisasikan dengan bahasa, yang itulah salah satu fungsi dari bahasa, karena ekspresi manusia dapat disalurkan juga melalui bahasa. Disinilah letak keberagaman fungsi bahasa. Fungsi bahasa yang jamak diketahui adalah sebagai alat komunikasi, walaupun bahasa juga dapat dipakai sebagai sarana integrasi masyarakat dan cara melakukan adaptasi sosial 
kemasyarakatan atas situasi tertentu dan berfungsi dalam melaksanakan kontrol sosial.

Fungsi bahasa yang paling efektif adalah sebagai sarana penyampai gagasan, pikiran, maksud dan tujuan kepada khalayak. Bahasa sebenarnya juga termasuk salah satu unsur kebudayaan. Sebagai salah satu manifestasi kebudayaan, peran penting bahasa sangat nampak dalam kehidupan manusia. Kebudayaan apapun memakai bahasa sebagai unsur pokok dalam kehidupan masyarakat. Pembuktiannya adalah bahasa masyarakat yang beranekaragam, baik dalam lingkup yang luas (internasional), maupun bahasa nasional.

Kehidupan manusia tidak terlepas dari bahasa, karena setiap kegiatan manusia memungkinkan dipakainya bahasa. Selain dipakai sebagai alat komunikasi secara langsung, bahasa juga dipakai dalam komunikasi secara tidak langsung yaitu dalam bentuk tulis. Baik komunikasi secara langsung maupun tidak langsung merupakan peranan bahasa dalam fungsinya sebagai penyalur ekspresi manusia dalam menyampaikan isi hati dan melakukan komunikasi dengan sesamanya.

Perkembangan waktu dan zaman turut melakukan perubahan dan perkembangan serta variasi-variasi yang terus bertambah dalam bahasa. Sehingga perkembangan bahasa tersebut sudah menjadi ciri umum bagi negara manapun yang mengakibatkan munculnya sifat-sifat tersendiri dalam bahasa suatu negara. Ilmu pengetahuan dan teknologi tidak akan berkembang dengan baik tanpa adanya bahasa.

Penggunaan dan pemakaian bahasa Arab di dunia internasional saat ini selain masif juga mencakup segala aspek kehidupan dari yang bersifat konvensional sampai digital dari dunia pertanian, pendidikan, perdagangan, bisnis, informasi, hingga industri. Bahasa Arab memiliki peran yang sangat penting karena bahasa Arab juga sudah menjadi bahasa pemrograman digital dalan semua aspek kehidupan. Dari aplikasi-aplikasi yang bersifat sederhana hingga yang rumit dan bersifat industrial. Dan dunia arab hari ini menunjukkan yang notabene menggunakan bahasa arab menjadi pusat kemajuan-kemajuan dunia seperti UEA dengan Abu Dhabi sebagai ibukotanya dan lain sebagainya.

Fenomena global yang seperti ini meniscayakan adanya tuntutan perubahan di Indonesia termasuk di dalamnya adalah pada sektor pendidikan tinggi. Pascasarjana IAIN Tulungagung tidak mau ketinggalan dalam hal ini untuk menjawab tantangan penggunaan bahasa Arab di era revolusi industri 4.0.

Bahasa yang masuk dalam struktur hierarkis budaya, pada dasarnya turut memiliki kedudukan, fungsi, dan peran ganda, yaitu sebagai akar dan produk budaya tertentu dan menjalankan fungsi sebagai media berfikir dan sebagai sarana pendukung majunya pertumbuhan dan perkembangan ilmu pengetahuan dan teknologi. Tanpa peran yang dimiliki bahasa tersebut, ilmu pengetahuan dan 
teknologi tidak mampu maju dan berkembang. Maka dari itu, kecermatan dalam memakai bahasa adalah pembuktian dari kecermatan mengolah pikir karena bahasa adalah cerminan dari daya nalar (pikiran) manusia. Fokus penelitian ini bertempat di Pascasarjana IAIN Tulungagung karena beberapa alasan yang signifikan. Pertama, IAIN Tulungagung adalah termasuk pilot project tingkat IAIN di Indonesia karena mampu mengikuti perkembangan zaman khusunya menghadapi era revolusi industri 4.0 dan sudah diakui oleh Kemenristekdikti dan juga Kemenag. Kedua, Pascasarjana IAIN Tulungagung mampu terus berkembang dengan adanya penambahan jurusan setiap tahunnya dan semakin meningkatnya nilai akreditasi pada masing-masing jurusan. Ketiga, jurusan bahasa Arab di Pascasarjana IAIN Tulungagung mampu mengikuti era revolusi industri 4.0 dengan adanya artikel yang terbit pada jurnal baik nasional maupun internasional yang terus bertambah setiap tahunnya.

\section{Hasil dan Pembahasan}

Di antara usaha-usaha Pascasarjana IAIN Tulungagung dalam rangka menjawab tantangan bahasa Arab sebagai alat komunikasi di era revolusi industri 4.0 yaitu dengan menselaraskan pemahaman pada level teoritis, edukatif andragogis, praksis, komunikatif dan industrial ; fungsi bahasa, teori pendidikan dalam pembelajaran bahasa, implementasi teori ilmiah, unsur-unsur komunikasi bahasa, bahasa Arab, fungsi bahasa Arab sebagai alat komunikasi, problematika bahasa arab sebagai alat komunikasi di era revolus industri 4.0 dan tantangan bahasa Arab sebagai alat komunikasi di era revolusi industri 4.0.

\section{Fungsi Bahasa}

Setiap manusia hidup sebagai mahluk sosial yang terbagi dalam suku dan ras yang berbeda-beda. Mereka terikat oleh beberapa faktor keluarga dan lingkungan. Mereka bersatu dengan tujuan, harapan, rasa sakit, emosi-emosi dan lain sebagainya yang terhubung dengan sosial. Maka dari itu mereka memerlukan kebutuhan yang bisa memahamkan mahluk sosial ini untuk meluruskan hidupnya dan juga memenuhi berbagai urusan-urusannya. Kita tidak bisa membayangkan sekelompok manusia yang membuang cara pemahaman diantara mereka. Maka tidak diragukan lagi bahwa sekelompok manusia telah melakukan upaya ijtihad dari awal mereka ada dalam rangka agar tercapainya pemahaman tersebut. Sehingga telah diambilah langkah-langkah seperti sinyal, gerakan, dan simbol sebagai sarana menuju pemahaman ini. Setelah melalui usaha-usaha tersebut maka bahasa berfungsi sebagai sarana pemahaman antara manusia ${ }^{1}$. 
Fungsi bahasa adalah sebagai sarana komunikasi setiap manusia yang berwujud simbol bunyi yang dihasilkan melalui alat ucap manusia ${ }^{2}$. Beberapa tokoh merasa canggung ketika menyatakan bahwa pada kenyataannya bahasa bukanlah alat utama dan satu-satunya untuk melakukan komunikasi. Para tokoh tersebut mengatakan bahwa ketika terdapat dua orang yang melakukan komunikasi dengan cara tertentu yang juga mereka sepakati maka itu termasuk dari komunikasi yang dilakukan tanpa menggunakan bahasa. Cara itu mereka wujudkan dalam bentuk bunyi gendang atau tong-tong, lukisan-lukisan, asap api, dan sebagainya. Teori yang meragukan fungsi bahasa sebagai alat utama komunikasi tersebut harus pula mengakui kelemahannya karena bila dibandingkan dengan bahasa, maka setiap alat yang digunakan untuk berkomunikasi selain alat ucap manusia tadi terlalu banyak memiliki segi kelemahan.

Cara komunikasi yang dilakukan dengan sebuah alat dengan mempergunakan media di atas hanya memberikan ruang sempit dalam komunikasi antar individu apalagi dalam tingkat sosial masyarakat. Berbeda dengan bahasa yang mampu memenuhi luas dan kompleksnya kebutuhan manusia dalam berkomunikasi. Bahasa yang dimaksud adalah bunyi yang timbul dari alat ucap manusia. Bukannya asal bunyi. Dan bunyi tersebut harus merupakan simbol atau perlambang.

Alat terpenting dalam komunikasi sehari-hari yang dilakukan setiap manusia baik dalam bentuk lisan atau tulis adalah bahasa. ${ }^{3}$ Masyarakat Indonesia yang setiap hari menggunakan bahasa Indonesia secara tidak sadar merasakan tidak perlunya mendalami dan mengetahui berbagai segi dalam bahasa Indonesia secara lebih jauh. Efek negatifnya adalah orang Indonesia, sebagai penutur pertama bahasanya, bukanlah termasuk ahli dalam bahasanya sendiri. Suatu kelemahan yang patut disesali. Komunikasi lisan dengan menggunakan nonstandar dalam berbahasa sehari-hari menyebabkan kita tidak teliti berbahasa. Akibat yang muncul adalah tidak mampunya para penutur pertama bahasa Indonesia ketika meletakkan bahasa lisan tersebut ke dalam bahasa tulis atau dalam bentuk bahasa yang dikatakan standar dan teratur.

Sesungguhnya bahasa inilah yang sampai kepada manusia akan tetapi belum sempurna dari segi suara, pengetatan kata-kata, dan keakuratan maknamakna yang berbeda kecuali dalam fase yang sistematis. Sehingga jika kita ambil dari segi pertumbuhan linguistik dari manusia saat mulai mereka kecil sampai mereka dewasa masih terlihat kurangnya tahap-tahapan yang berjalan di dalam struktur bahasa mereka. Sehingga kita bisa menggambarkan bahwa Bahasa benar-benar di pindahkan dari suara ke potongan kata-kata lalu mengalami kata

${ }^{2}$ Gorys Keraf, Komposisi: Sebuah Pengantar Kemabiran Bahasa (Ende : Nusa Indah, 1997) h.1

${ }^{3}$ Felicia, Peranan dan Fungsi Bahasa (Jakarta: Rineka Cipta, 2001) h. 1 
untuk situasi dan terminologi. Ketika bahasa telah melewati tahap perkembangan masa kanak-kanak maka bahasa telah sampai pada tahap kemajuan dan pembaharuan yaitu masuk pada fase gramatikal dan kontrol bahasa yang memberikan protect dari kerusakan atau kesalahan dalam berbahasa, lalu pengucapan menjadi sarana dalam pembenahan dan kemewahan dalam berbahasa ${ }^{4}$.

Kita, para penutur pertama bahasa Indonesia, cenderung terlihat kaku saat menggunakan bahasa untuk kepentingan yang lebih terarah dan sistematis untuk tujuan tertentu. Kita akan berbahasa dengan mencampur-adukkan bahasa standar dengan bahasa nonstandar, lebih jauhnya kita akan mencampur-adukkan istilah asing ke dalam kalimat-kalimat yang kita uraikan. Padahal sebenarnya bahasa bersifat manipulatif, sangat longgar. Kepentingan ataupun maksud tersembunyi yang kita inginkan dapat kita manipulasi melalui bahasa. Salah satu contoh riilnya adalah bahasa-bahasa para politisi. Cara memanipulasi bahasa tersebut, dapat kita gunakan dengan mengetahui fungsi-fungsi bahasa terlebih dahulu yaitu antara lain :

1. Fungsi Bahasa di dalam kehidupan individu

Bahasa adalah alat komunikasi individu dengan orang lain dan melalui cara ini mereka dapat menginformasikan maksud yang mereka inginkan dan mendapatkan tujuannya. Oleh karenanya, dengan cara itulah mereka dapat mengekspresikan cara pandangnya, fikirannya, rasa sakit, harapan dan juga emosinya.

2. Fungsi Bahasa di dalam kehidupan social

Bahasa adalah alat sosial dan cara memahami antara individu dan kelompok. Bahasa juga digunakan untuk menghadapi situasi-situasi yang penting sehingga membutuhkan keterampilan berbahasa yang khusus seperti kalam, istima', kitabah dan qiroah. Keempat teknik berbahasa ini sebagai alat yang sangat penting untuk memberikan pemahaman dari segala aspek berbahasa. Sangat jamak diketahui bahwa fungsi ini adalah salah satu fungsi terpenting dalam berbahasa dalam kehidupan sosial atau masyarakat ${ }^{5}$.

Fungsi paling pokok dan efektif yang dimiliki bahasa adalah kemampuannya dalam memenuhi kebutuhan individu dan sosial yaitu sebagai alat ekspresi manusia, alat dalam mengadakan integrasi dan memberikan cara adaptasi sosial kepada masyarakat sosial, dan juga alat yang berfungsi sebagai kontrol sosial ${ }^{6}$.

\footnotetext{
${ }^{4}$ Abdul Alim Ibrahim, Al Muwajiibul Al-Fanni, h. 43

${ }^{5}$ Ibid., h. 43

${ }^{6}$ Gorys Keraf,. h. 3
} 
Pada dasarnya, bahasa mempunyai fungsi-fungsi tertentu yang dapat yakni sebagai alat untuk mengekspresikan diri.

a. Bahasa sebagai Alat Ekspresi Manusia

Perkembangan bahasa dimulai saat seorang anak memainkan bahasa. Ia memakainya sebagai ekspresi diri atas keinginan yang ia rasakan. Sasaran utamanya masihlah bersifat konstan, yakni ayah-ibunya. Seiring dengan berlanjutnya usia, ekspresi anak tersebut turut memperlebar fungsi bahasa, yaitu sebagai alat komunikasi dengan lingkungan di sekitarnya. Ketika menginjak dewasa, manusia mempergunakan kedua fungsi bahasa tersebut secara beriringan, baik sebagai sarana ekspresi maupun komunikasi. Selayaknya penulis yang berekspresi dan berkomunikasi dalam bentuk karya tulisnya.

Sebenarnya, seorang ilmuwan yang menghadirkan kemampuannya pada bidang ilmu spesifik melalui karya ilmiah yang ia kerjakan adalah juga termasuk sarana ekspresi diri. Maka, sebuah tulisan ataupun karya ilmiah adalah cara yang dapat kita gunakan untuk mengekspresikan diri kita dalam mencapai tujuan yang kita inginkan. Contoh lainnya, tulisan yang kita hasilkan melalui tugas-tugas kuliah adalah hasil ekspresi diri kita. Saat kita mengerjakan tugas, pikiran kita turut menentukan siapakah pembacanya nanti. Kita akan menggunakan bahasa yang baik, standar, formal dan sistematis terstruktur karena bahasa tersebut akan kita pertanggungjawabkan di hadapan dosen pemangku mata kuliah dan di hadapan kawan-kawan sekelas kita. Berbeda halnya saat kita menulis buku. Kita tidak perlu memikirkan siapa pembacanya nanti.

Pemakai bahasa yang mengekspresikan diri dan menggunakan bahasa sebagai alatnya, tidak perlu memikirkan atau mempertimbangkan siapa pendengar, pembaca, ataupun khalayak umum yang akan menerima bahasa pemakai bahasa tersebut. Ia hanya peduli pada kepentingan dan kebutuhan pribadinya saja. Maka, cara tersebut bukanlah merupakan fungsi bahasa sebagai alat komunikasi. Bahasa, sebagai alat penyalur ekspresi manusia, menyatakan secara eksplisit apapun yang ada dalam angan manusia, sekurang-kurangnya untuk menunjukkan eksistensi keberadaannya. Ekspresi diri dapat didorong dengan beberapa unsur antara lain : - agar perhatian orang lain tertuju pada kita, - pembebasan manusia dalam tekanan emosi. Pada taraf awal, bahasa anak-anak adalah cara menunjukkan eksistensi dirinya. ${ }^{7}$

b. Bahasa sebagai Alat Integrasi dan Adaptasi Sosial

Para tokoh menganggap bahasa adalah salah satu unsur kebudayaan. Keunggulan manusia adalah kemampuannya dalam memanfaatkan pengalaman mereka, mengambil pelajaran dari pengalaman itu, serta mampu berkomunikasi dengan manusia yang lain. Setiap individu dalam komunitas masyarakat tertentu

${ }^{7}$ Ibid. h. 4 
dapat disatukan melalui bahasa. Oleh karena itu, selain sebagai alat komunikasi, bahasa memiliki fungsi pemersatu antar individu dan kelompok sosial dalam suatu komunitas, serta turut aktif melalui kegiatan kemasyarakatan, tanpa menimbulkan ekses-ekses negatif dengan menghindari bentrokan-bentrokan untuk mendapatkan efisiensi sejauh mungkin. Dengan cara tersebut, bahasa dapat dijalankan sebagai alat integrasi (pembauran) yang efektif bagi individu dengan masyarakat sosialnya. ${ }^{8}$

Fungsi lain bahasa selain sebagai alat komunikasi, berfungsi pula sebagai alat integrasi dan adaptasi sosial. Pada saat kita berada pada situasi dan kondisi lingkungan sosial tertentu, kita akan melakukan adaptasi dengan memilih bahasa yang sesuai dengan situasi dan kondisi dalam lingkungan sosial tersebut. Kita akan menggunakan bahasa yang berbeda pada individu yang berbeda. Sebagai contoh, bahasa standar akan kita gunakan sat berkomunikasi dengan orang yang lebih tua, dan bahasa nonstandar akan kita gunakan saat berkomunikasi dengan teman sejawat.

Implementasi fungsi bahasa sebagai alat adaptasi sosial adalah saat kita mempelajari bahasa asing. Selain materi tentang kaidah-kaidah bahasa, kita turut pula mencari tahu bagaimana suatu bahasa tersebut digunakan dalam kehidupan sehari-harinya. Misalnya, suatu kata A dapat digunakan dalam kondisi 1, dan tidak boleh menggunakan kata B dalam kondisi 1 tersebut. Orang Jawa akan menggunakan kata "sampeyan atau panjenengan" saat menyapa orang yang lebih tua, dan dirasa sangat tidak sopan saat menggunakan kata "kowe" dalam situasi yang sama tersebut. Maka dari itu, orang asing yang sedang mempelajari bahasa Jawa harus mengetahui dan memahami kondisi-kondisi bagaimana suatu kalimat dapat digunakan. Begitu pula saat kita mempelajari bahasa asing, kita dituntut untuk mengetahui tata cara berbahasa dalam budaya bahasa tertentu agar tidak salah paham dalam berkomunikasi. Dengan menguasai bahasa suatu bangsa, fungsi utamanya adalah kemudahan dalam berbaur dan beradaptasi dengan bangsa tersebut.

c. Bahasa sebagai Alat Kontrol Sosial

Bahasa memiliki fungsi efektif sebagai alat kontrol sosial. Kontrol sosial ini mencakup kontrol pada diri kita sendiri pun pula kepada masyarakat. Berbagai sosialisasi, konferensi, maupun pendidikan disampaikan melalui bahasa. Buku-buku baik pelajaran sekolah maupun lebih ilmiah adalah salah satu contoh bagaimana penggunaan bahasa sebagai alat kontrol sosial. Contoh yang paling menonjol adalah penggunaan bahasa dalam ceramah agama atau dakwah. Orasi ilmiah atau politik juga termasuk contoh lebih jauh pengunaan bahasa sebagai alat kontrol sosial. Diskusi atau talk show di radio, televisi bahkan 
sekarang dalam bentuk live streaming juga termasuk dalam fungsi bahasa seperti di atas. Termasuk di dalamnya, iklan layanan masyarakat atau layanan sosial.

Aktifitas-aktifitas berbahasa dalam gambaran di atas membuat kita memperoleh cara pandang baru, perilaku, sikap ataupun tindakan yang baik. Begitu pula kita dapat menemukan cara mendengar perbedaan pendapat dengan seksama dan mampu menerima perbedaan itu dengan lapang dada. Menulis, adalah contoh mudah fungsi bahasa sebagai alat kontrol sosial. Karena dengan menulis, emosi kita dapat tersalurkan. Emosi yang tertuang dalam bentuk tulisan, dapat membantu kita menekan rasa marah, sedih, bahagia, dan emosiemosi lain yang sebelumnya belum dapat kita salurkan karena satu hal tertentu. Penuangan emosi dalam bentuk tulisan tersebut adalah contoh konkrit fungsi bahasa sebagai alat kontrol sosial.

\section{Teori Pendidikan dalam Pembelajaran Bahasa}

1. Pendidikan zaman klasik

Pada zaman klasik, bahasa dalam ranah pendidikan adalah sesuatu pembelajaran untuk kepentingan dirinya sendiri dan budaya. Akan tetapi fungsi ini telah berubah karena mengabaikan aspek fungsional linguistik. Pandangan lama ini telah menghasilkan banyak kesalahan. Beberapa diantaranya dikarenakan keterkaitan bahasa dengan kurikulum berupa metode pengajarannya dan tujuan mempelajari bahasa itu sendiri'.

Para ahli bahasa berpendapat, bahwa bahasa Arab bersatu adalah karena percampuran bahasa yang berasal dari penduduk-penduduk yang ada di semenanjung jazirah Arab. Walaupun mereka tidak mampu memastikan terbentuknya bahasa Arab seperti yang kita ketahui sekarang dan pula tidak mengetahui penyebab pasti percampuran bahasa tersebut. Berbagai riwayat dari peninggalan zaman batu di selatan dan utara semenanjung arab hanya menunjukkan perbedaan bahasa dari zaman tersebut dengan bahasa Arab saat ini. Perbedaan itu dapat ditunjukkan dengan labjab-labjab (dialek-dialek), i'rab, isytiqaq-nya serta persamaan kata antar bahasa dari lintas zaman tersebut.

Sejarah sastra Arab adalah bagian penting dimana kita dapat mengetahui bagaimana perjalanan sastra arab yang dimulai dari zaman kuno sampai saat ini. Perjalanan sastra Arab diakui para ahli sastra sebagai perjalanan bahasa yang panjang dan penuh gejolak. Dalam buku-buku klasik, terdapat enam periodisasi dalam sejarah sastra Arab yaitu Periode Jahiliyah, Periode Permulaan Islam, Periode Bani Umayyah, Periode Abbasiyah, Periode Abad Pertengahan, Periode Era Modern ${ }^{10}$.

${ }^{9}$ Abdul Alim Ibrahim, Al Muwajjihul Al-Fanni., h. 46

${ }^{10}$ Amin nasir, Bahasa arab era klasik dan modern, (arabia : Jakarta, 2014) e-jurnal h. 30-43 


\section{Pendidikan zaman modern}

Bahasa yang dipahami oleh pendidikan modern yaitu sebagai sarana ekspresi individu terhadap pemahaman budaya dan alat sosial yang memungkinkan komunikasi antar individu tersebut dan manautkan kesepahaman diantara mereka. Teori ini didasarkan atas dua hal yaitu bahwa bahasa sebagai sarana sosial untuk memahamkan antar seseorang dan bahasa diwajibkan untuk dipelajari berdasarkan urgensinya dan fungsinya di dalam kehidupan. Maka dari itu, pengajar harus mengetahui bahwa ia memerlukan kedua dasar teori pendidikan modern tersebut dalam konteks pengajarannya ${ }^{11}$.

Pada masa ini ditandai dengan kemunculan penulisan prosa yaitu cerpen (cerita pendek) berbahasa Arab. Ada pula novel dan drama, yang mulai muncul di akhir abad 19. Puisi pun pada akhirnya mengalami signifikansi dalam perkembangannya. Gaya puisi seperti terdapat dalam 'Ilm al-'Arūd sudah banyak dilepas sebagai patokan utama para sastrawan Arab modern dalam membuat puisi-puisi mereka. Puisi bebas adalah gaya yang disukai mpara penyair dewasa ini, kendati ada juga penyair yang masih dengan gaya lama tetapi memodifikasinya dengan melepaskan diri dari syarat-syarat lama tertentu, seperti Mahmud Ali Taha (w.1949). Karya puisi yang dihasilkannya terasa halus, romantis dan menyentuh, tetapi di sisi lain sangat religius. Mahmud Ali Taha, oleh beberapa pengamat, dikatakan mengikuti romantisme Perancis abad ke-19, utamanya Lamartine. Ia juga memberikan jarak dengan penyair-penyair modern semi-klasik terdahulu, seperti Ahmad Syauqi atau Hafidz Ibrahim (1872-1932).

Dalam sastra Arab modern, walaupun banyak yang berasal dari Libanon dan Suriah, para penyair Mesir diakui sebagai awal pembuka gerbang. Kepindahan mereka ke Mesir adalah karena tersalurkannya bakat yang mereka miliki saat berada di negara ini. Terutama karena Mesir memiliki kampus terkenal yang juga termasuk rujukan para pencari ilmu, yaitu Unversitas al-Azhar Cairo. As-Säir al-Mabjar atau The Emigran Poet adalah istilah yang disematkan untuk para penyair di kawasan Arab termasuk Arab Saudi yang berimigrasi umumnya ke Amerika Selatan.

Banyak terjadi perubahan dari bahasa yang masih menggunakan gaya tradisional menuju bahasa modern. Gaya tradisional yang memakai kosa kata klasik dengan kalimat berbunga semi-hiperbolis dan panjang lebar akibat pengaruh pleonasme berganti dengan gaya yang mengikuti pola gaya zaman yang sejalan yaitu serba singkat, dan serba cepat. Perkembangan sastra arab modern dapat kita ketahui melalui ciri khasnya yaitu melalui bahasa percakapan (vernacularism) dalam dialog, walaupun rinciannya masih dengan bahasa baku. Perubahan gaya ini terdapat juga penentangnya. Ada golongan tertentu yang merencanakan untuk memodifikasi huruf Arab dengan tujuan dapat pula dibaca

${ }^{11}$ Abdul Alim Ibrahim, Al Muwajjibul Al-Fanni., h. 46 
dalam huruf Latin. Jika golongan tadi hanya bertujuan memodifikasi, maka kelompok yang ada di Libanon mencoba menggantikan huruf Arab dengan huruf Latin. ${ }^{12}$

\section{Implementasi Teori Ilmiah}

1. Pada tingkat guru

Ketika seorang pengajar mentautkan ilmu bahasa dengan ilmu sosial maka secara teori ia telah beranjak dari metode taqlidiyah (tradisional). Sampai akhirnya, pengajar dapat mengajar dan melatih murid-muridnya sampai pada tahap penggunaan gramatikal bahasa yang baik dan benar. Dengan menggabungkan pengajaran dengan kehidupan, pengajar turut melatih peserta didik dengan keempat ketrampilan berbahasa dengan baik dan benar.

2. Pada tingkat kurikulum

Pengajar tidak hanya berputar-putar pada kurikulum saja tetapi juga melatih seni dengan menitikberatkan pada empat keterampilan berbahasa yaitu berbicara, mendengar, menulis dan membaca. Tidak memasukkan tema-tema yang memberatkan yang tidak bisa sampai secara langsung pada pemahaman murid dengan memakai fungsi-fungsi dasar bahasa.

3. Pada tingkat kondisi Pendidikan

Bahasa bukan tema pembelajaran saja, maka dari itu pendidikan tidak hanya membatasi bahasa pada jadwal pelajaran tertentu, akan tetapi melatih peserta didik untuk memakai bahasa yang benar di setiap waktu yang memungkinkan ${ }^{13}$.

\section{Unsur-Unsur Komunikasi Bahasa}

Para ahli telah sepakat bahwa bahasa adalah alat komunikasi sosial diantara manusia dan sarana pemahamannya. Pentingnya bahasa ini sangat jelas ketika seseorang hidup diantara mahluk sosial dalam waktu tertentu yang sebelumnya belum mengenal bahasa mereka. Tujuan akhir dari komunikasi bahasa adalah merujuak pada kesatuan pemahaman. Pemahaman adalah kondisi yang menyamakan persepsi antar dua sisi yaitu penutur dan objeknya. Bahasa memiliki 4 bidang bahasa yaitu berbicara, mendengar, menulis dan membaca. Dari keempat bidang itulah tugas seorang pengajar memberikan pemahaman terhadap suatu bahasa. Maka dari itu pengajar harus mampu berbicara sebagai sarana menyampaikan sesuatu dan begitupun dengan maharah lainnya yang disampaikan dengan tujuan memberikan pemahaman atas apa yang ingin ia sampaikan ${ }^{14}$.

\footnotetext{
12 Amin nasir, Bahasa arab era klasik dan modern, h. 41-43

13 Abdul Alim Ibrahim, Al Muwajjibul Al-Fanni., h. 46-47

${ }^{14}$ Ibid., 47-48
} 


\section{Bahasa arab}

Bahasa Arab adalah bahasa yang dipakai oleh orang Arab dan umat islam dan bahasa yang mendapatkan kedudukan tinggi oleh kaum arab ${ }^{15}$. Bahasa mempunyai sifat komunikatif bagi para penuturnya. Karena sifat itu, pada dasarnya tidak terdapat keunggulan antar bahasa satu dengan bahasa lainnya. Kesamaan semua bahasa adalah fungsi utama yang dimiliki yaitu sebagai alat komunikasi. Kesepahaman antar pelaku komunikasi dapat dimediai dengan bahasa. ${ }^{16}$

Bahasa Arab adalah sebuah bahasa Semit atau Semitik yang muncul dari daerah Timur Tengah. Bahasa ini adalah sebuah bahasa yang dipakai oleh para penutur dengan jumlah paling banyak dalam lingkungan keluarga bahasa Semitik. Bahasa Arab dan bahasa Ibrani termasuk kerabat dekat bahasa Semitik ini. Bahasa-bahasa ini dituturkan di seluruh dunia Arab, dan bahasa baku bahasa Arab diterima di seluruh dunia. Masyarakat yang tinggal di kawasan arab, secara geografis, berasal dari satu ras manusia, yaitu Kaukasia dan Asia Barat. Bukti empiris pendapat ini adalah penemuan arkeolog abad ke-18 dan ke-19 Masehi yang membuktikan terdapat suatu masyarakat dan bahasa tertentu yang tertulis dalam perjanjian lama atau yang disebut Semit ${ }^{17}$.

Salah satu pakar bahasa Arab, yaitu Syaikh al-Ghulayayniy mengatakan bahwa bangsa Arab menggunakan bahasa Arab dalam mengutarakan maksud/tujuan mereka. Sedangkan Ahmad al-Hasyimiy menyatakan bahwa bahasa Arab adalah bunyi yang mengandung sebagian huruf hijaiyyah. Pendapat kedua pakar di atas, mengenai definisi bahasa Arab, meskipun secara redaksional terlihat berbeda akan tetapi mempunyai kesamaan maksud dan tujuan. Kesimpulan yang dapat ditarik oleh penulis adalah bahwa bahasa Arab adalah suatu bunyi yang mengandung huruf hijaiyyah yang digunakan bangsa Arab untuk mengutarakan maksud/atau tujuan tertentu.

\section{Fungsi Bahasa Arab sebagai Alat Komunikasi}

Komunikasi adalah efek jauh yang muncul saat melakukan ekspresi diri. Komunikasi hanya berjalan sepihak saat uraian yang kita sampaikan tidak mampu masuk dalam pemahaman lawan bicara kita. Kita dapat mengetahui kehendak seseorang baik nenek moyang kita atau orang-orang yang sezaman dengan kita juga melalui komunikasi. Fungsi bahasa, kususnya bahasa Arab, karena sebagai alat komunikasi maka digunakan sebagai sarana berekspresi, mewujudkan perasaan kita, dan mampu melakukan integrasi dengan sesama

15 Ibid., h. 48

16 Acep Hermawan, Metodologi Pembelajaran Bahasa Arab, (Bandung: PT Remaja Rosdakarya Offset, 2011), h. 58

${ }^{17}$ Taufiqurramhan, leksikologi Bahasa arab, ( UIN Malang press : Malang, 2008) h. 177 
warga yang lain. Bahasa turut aktif dalam setiap kegiatan kemasyarakatan, mengarahkan dan merencanakan masa depan. ${ }^{18}$

Bahasa yang kita gunakan sebagai sebagai alat komunikasi, tentunya kita tujukan agar kita dapat menyampaikan yang kita inginkan kepada orang lain sampai ia memahami keinginan itu. Gagasan kita tersebut seharusnya mampu diterima orang lain sampai pada penerimaan keyakinan pandangan yang kita miliki, pengaruh yang timbul dari gagasan itu sampai orang lain mau membeli gagasan yang kita miliki. Kita memakai bahasa dengan tujuan mendapatkan perhatian dari khalayak sasaran kita.

\section{Problematika Bahasa Arab sebagai Alat Komunikasi di Era Revolusi Industri 4.0 pada Pascasarjana IAIN Tulungagung}

Adapun problematika pembelajaran bahasa Arab di Pascasarjana IAIN Tulungagung dalam menghadapi era revolusi industri 4.0 sebagaimana berikut:

1. Motivasi yang rendah di kalangan mahasiswa untuk belajar maharah istima' menggunakan laboratorium bahasa, padahal pihak pascasarjana menyediakan sarana laboratorium yang memadai.

2. Kesadaran yang rendah baik dari dosen maupun mahasiswa untuk membentuk bi'ah arabiyyah, padahal misi pascasarjana IAIN Tulungagung adalah menjadikan bahasa Arab dan bahasa Inggris sebagai bahasa pengantar perkuliahan. Diantara bi'ah arabiyyah adalah penggunaan aplikasi pembelajaran berbasis bahasa Arab seperti Belajar Bahasa Arab, Learn Arabic, dan Speak Arabic.

3. Input mahasiswa yang heterogen. Kemampuan empat maharah terutama kalam dan kitabah masing-masing mahasiswa terpaut perbedaan sangat signifikan. Hal ini dikarenakan masih banyak mahasiswa Pascasarjana yang bukan berlatarbelakang S1 PBA akan tetapi berasal dari jurusan lain yaitu PGMI, PAI, maupun TMT ${ }^{19}$. Adapun solusi yang ditawarkan oleh peneliti adalah penyelenggaraan FGD (Focus Group Discussion) dengan tema pelatihan empat maharah bahasa Arab yang dimonitori oleh para dosen PBA Pascasarjana IAIN Tulungagung.

4. Dari enam dosen (dosen tetap prodi PBA Pascasarjana IAIN Tulungagung) yang ada, dua dosen mengaku belum sempurna dalam menguasai IT terutama pembelajaran daring, dan e-learning system. ${ }^{20}$ Sedangkan solusi yang ingin ditawarkan peneliti adalah kerjasama yang dilakukan PBA Pascasarjana IAIN Tulungagung dengan para pakar IT di wilayah Tulungagung melalui pihak LP2M (Lembaga Penelitian dan Pengabdian Masyarakat) IAIN Tulungagung

${ }^{18}$ Keraf, Komposisi...... h. 4

19 Data diperoleh dari hasil wawancara dengan sekretasis PBA Pascasarjana IAIN Tulungagung Bapak Muhammad Siradjudin, M.Pd.I pada tanggal 25 Juli 2019 jam 10.30 WIB

20 Data diperoleh dari hasil wawancara dengan dosen PBA Pascasarjana IAIN Tulungagung pada tanggal 05 Juli 2019 jam 08.30 WIB 
untuk melakukan workshop pelatihan IT bagi para dosen Pascasarjana IAIN Tulungagung khusunya para dosen mata kuliah bahasa Arab.

5. Media pembelajaran bahasa Arab mengalami kendala akses internet yang terbatas dan tidak lancar, di mana akses internet tidak bisa dijangkau oleh seluruh mahasiswa terlebih saat pelajaran berlangsung. ${ }^{21}$ Solusi yang ditawarkan peneliti adalah merekrut para pakar IT untuk ditempatkan di Pascasarjana IAIN Tulungagung sebagai pengelola akses tersendiri yang terpisah dari pihak pusat rektorat IAIN Tulungagung.

\section{Tantangan Bahasa Arab sebagai Alat Komunikasi di Era Revolusi Industri 4.0 pada Pascasarjan IAIN Tulungagung}

Pascasarjana ditantang oleh MEA (Masyarakat Ekonomi Asean) untuk berperan dalam pertukaran mahasiswa di tingkat ASEAN. Hal tersebut telah dijawab oleh Pascasarjana semenjak tahun 2016 telah merekrut mahasiswa berasal dari Ma'had Al-Jauhariyah Al-Islamiyah dari Kubang Buaya, Pattani, Thailand $^{22}$ antara lain Basmah Salaeh dan Basmah Yiming yang telah berhasil lulus dan diwisuda pada tanggal 22 Juni $2019 .^{23}$

1. Pascasarjana IAIN Tulungagung ditantang mampu berkontribusi dalam menyemarakkan Bahasa Arab sebagai bahasa Internasional. Implikasinya adalah bahasa Arab terus dipakai oleh penutur bahasa dari berbagai negara baik arab maupun non-arab. Para penutur tersebut memungkinkan bahasa Arab sebagai alat komunikasi mereka dalam berbagai kegiatan termasuk kegiatan resmi kenegaraan. Sehingga fungsi bahasa Arab sebagai alat komunikasi yaitu untuk menyampaikan pesan para penuturnya dari orang perorang yang dalam konteks sekarang telah digunakan dalam kancah Internasional. Hal tersebut telah dijawab oleh PBA Pascasarjana IAIN Tulungagung dengan mengadakan Seminar Internasional Bahasa Arab dengan tema "Bahasa Arab Membangun Dialog Lintas Budaya di Kancah Internasional" pada tanggal 03 Mei 2019 yang dihadiri oleh Prof. Dr. Abdel Aziz Abbaci dari Aljazair. ${ }^{24}$

${ }^{21}$ Data diperoleh dari hasil observasi di Pascasarjana IAIN Tulungagung pada tanggal 20 Juli 2019 jam 08.00-10.00 WIB.

22 Data dapat diakses melalui akun resmi IAIN Tulungagung URL http:// www.iaintulungagung. ac.id/ berita/ 957-iain- tulungagung- terima- lima- calon- mahasiswa- asalThailand

${ }^{23}$ Data diperoleh dari hasil wawancara dengan Kojin selaku Kaprodi PBA Pascasarjana IAIN Tulungagung pada tanggal 15 Juli 2019 jam 14.45 WIB. Data juga dapat diakses melalui akun resmi IAIN Tulungagung URL http://www.iain-tulungagung.ac.id/berita/1226-diwisuda dan dalam akun media sosial facebook resmi PBA Pascasarjana IAIN Tulungagung URL https://www.facebook.com/pba. tulungagung

${ }^{24}$ Data diperoleh dari hasil wawancara dengan Akhya' selaku Direktur Pascasarjana IAIN Tulungagung pada tanggal 19 Juli 2019 jam 09.30 WIB. Data juga dapat diakses melalui akun resmi IAIN Tulungagung URL http:// www.iain-tulungagung.ac.id/ berita/ 1194pascasarjana -iain- tulungagung- gelar- seminar- internasional- bahasa- arab9 
2. Oleh karena itu, Pascasarjana IAIN Tulungagung harus mampu menjadikan bahasa Arab sebagai alat komunikasi untuk menjadi jawaban atas tantangan pembelajaran bahasa Arab dalam menghadapi era revolusi industri 4.0 karena era ini masuk dalam semua lini termasuk dalam pendidikan. Tantangan nyata yang dihadapi Pascasarjana IAIN Tulungagung adalah mengarahkan bahasa Arab sebagai alat komunikasi yang dapat digunakan dalam semua bidang kehidupan baik ekonomi, politik, bisnis disamping pendidikan itu sendiri. Hal itu dijawab oleh Pascasarjana IAIN Tulungagung dengan mewajibkan dosen bahasa Arab untuk menggunakan bahasa Arab sebagai bahasa pengantar dalam setiap perkuliahan. ${ }^{25}$ Pascasarjana IAIN Tulungagung juga mengadakan kegiatan "Academic Action in Ramadhan 2019" yaitu kegiatan kemahasiswaan yang dikemas dalam kegiatan akademik yang disesuaikan dengan kekhasan prodi masing-masing sebagai jawaban dalam menghadapi era revolusi industri 4.0. ${ }^{26}$

\section{Penutup}

Problematika pembelajaran bahasa Arab di Pascasarjana IAIN Tulungagung antara lain sebagai berikut; pertama, input mahasiswa yang heterogen. Kedua, adanya dosen PBA Pascasarjana IAIN Tulungagung yang belum menguasai IT. Ketiga, akses internet yang belum lancar.

Tantangan pembelajaran bahasa Arab di era revolusi industri 4.0 pada Pascasarjana IAIN Tulungagung adalah pertama, Pascasarjana IAIN Tulungagung ditantang oleh MEA (Masyarakat Ekonomi Asean) untuk berperan dalam pertukaran mahasiswa di tingkat ASEAN. Kedua, Pascasarjana IAIN Tulungagung ditantang mampu berkontribusi dalam menyemarakkan Bahasa Arab sebagai bahasa Internasional. Ketiga, Pascasarjana IAIN Tulungagung harus mampu menjadikan bahasa Arab sebagai alat komunikasi untuk menjadi jawaban atas tantangan pembelajaran bahasa Arab dalam menghadapi era revolusi industri 4.0 .

${ }^{25}$ Data diperoleh dari hasil observasi di Pascasarjana IAIN Tulungagung pada tanggal 20 Juli 2019 jam 14.00-16.00 WIB.

${ }^{26}$ Data diperoleh dari hasil wawancara dengan Akhya' selaku Direktur Pascasarjana IAIN Tulungagung pada tanggal 19 Juli 2019 jam 09.30 WIB. Data juga dapat diakses melalui akun resmi IAIN Tulungagung URL http:// www.iain-tulungagung.ac.id/ berita/ 1194 pascasarjana-iain- tulungagung- meriahkan- bulan- puasa- dengan- academic-action-inramadhan-2019 
298 | Arabiyatuna : Jurnal Bahasa Arab, Vol. 3, No. 2, 2019

\section{Bibliografi}

Felicia. Peranan dan Fungsi Bahasa. Jakarta: Rineka Cipta, 2001.

Hermawan, Acep. Metodologi Pembelajaran Bahasa Arab. Bandung: PT Remaja Rosdakarya Offset, 2001.

Ibrahim, Abdul Alim. Al Muwajjihul Al-Fanni. Qohiroh: Darul Maarif, 1968.

Keraf, Gorys. Komposisi: Sebuah Pengantar Kemahiran Bahasa. Ende: Nusa Indah, 1997.

Nasir, Amin. Bahasa Arab Era Klasik dan Modern. Jakarta: Arabia, 2014

Syuhadak. Pembelajaran Bahasa Arab bagi muslim Indonesia. Naskah Pidato Ilmiah pada Rapat terbuka Senat UIN Malang, 2006.

Taufiqurrahman. Leksikologi Bahasa Arab. Malang: UIN Malang Press, 2008.

Thu'aimah, Rusydi Ahmad. Ta'lim al-Lughah Lighairi al-Nathiqin biha. Beirut: Dar al-Fikr al-'Arabiy. 1989.

Thu'aimah, Rusydi Ahmad. al-Maharaat al-Lughawiyyah Mustawiyatuha. Kairo: Dar al-Fikr al-'Arabiy, 2004.

Yunus, Fathi Ali dan Muhammad 'abd Rauf al-Syeikh. Al-Marja'fi Ta'lim alLughah al-Arabiyyah li al-Ajanib. Kairo: Maktabah, 2003. 